\title{
THE RISK OF ABUSE OF VITAMIN SUPPLEMENTS
}

\section{RYZYKO NADUŻYWANIA WITAMINOWYCH SUPLEMENTÓW DIETY}

\author{
Katedra Biochemii i Chemii Medycznej Pomorskiego Uniwersytetu Medycznego w Szczecinie \\ al. Powstańców Wlkp. 72, 70-111 Szczecin \\ Kierownik: prof. dr hab. n. med. Dariusz Chlubek
}

\begin{abstract}
Streszczenie
$\mathrm{W}$ artykule przedstawiono wyniki badań na temat potencjalnych zagrożeń związanych z nadużywaniem witaminowych suplementów diety, które do niedawna uważano nie tylko za wysoce skuteczne, ale także całkowicie bezpieczne. Szczególną uwagę poświęcono witaminom A, E, D i C. Wskazano na konieczność kontrolowania przyjmowania witaminowych suplementów diety, a nawet ścisłego nadzorowania ich podaży pacjentom z grup ryzyka.

$\mathrm{H}$ a s $\nmid$ a: witaminowe suplementy diety - witamina A witamina $\mathrm{C}$ - witamina $\mathrm{D}$ - witamina $\mathrm{E}$.

\section{Summary}

The article presents the results of studies on potential risks associated with the abuse of vitamin supplements which until recently had been considered not only highly efficacious, but also completely safe. Particular consideration is given to vitamins $\mathrm{A}, \mathrm{E}, \mathrm{D}$ and $\mathrm{C}$. The necessity to control the intake of vitamin supplements and even to strictly supervise the supply to high risk patients is highlighted.
\end{abstract}

K e y w o r d s: vitamin supplements - vitamin A - vita$\min \mathrm{C}-$ vitamin $\mathrm{D}$ - vitamin $\mathrm{E}$.

\section{Introduction}

The intake of vitamin supplements have become not only a readily available and simple method to replenish the deficiencies of individual vitamins, but also a fashion propagated by media and manufacturers. Falling victim to that fashion as well as to the advertisement claims, many people are convinced that the intake of vitamins in the form of tablets or capsules can fully meet their demand and protect them from suffering from numerous more or less hazardous disorders. Meanwhile, a growing number of organizations assessing the efficacy of vitamin supplements are forced to discontinue or thoroughly modify their research programs due to increasing morbidity and even mortality among the study subjects. It turns out that some dietary supplements not only do not reduce, but paradoxically increase the risk of diseases. Dosage is another problem, since uncontrolled intake of products considered to be safe may bring about opposite results. This article is an attempt to summarize the current knowledge on the topic.

\section{Carotenoids}

The results of studies conducted in the 1980s and 1990s suggested that diets rich in fruit and vegetables reduced the risk of lung and gastrointestinal tract cancers $[1,2,3]$. The effect was attributed to, among others, the activity of $\beta$-carotene (provitamin A), which had been introduced as one of the most important antioxidants on the promises of its potential to reduce the risk of diseases associated with oxidative stress. However, an opposite correlation was demonstrated by Greenberg et al. [4]. Their studies in a group of healthy volunteers revealed that $\beta$-carotene not only did not protect from skin cancer but also increased the risk of lung cancer. Omenn et al. conducted a study in a group of patients with high risks of lung cancer due to smoking or exposure to asbestos [5]. The study group was given dietary supplements containing $\beta$-carotene and vitamin $A$, while 
the control group received placebo. After 2 years, the study was discontinued with conclusion that the incidence of lung cancer was similar in both groups (5.92 in the study group and 4.62 in the control group). The authors concluded that the intake of dietary supplements containing both $\beta$-carotene and vitamin $\mathrm{A}$ is not rational.

Having conducted cohort studies, Michaud et al. observed that simultaneous intake of $\alpha$-carotene and lycopene reduced the incidence of lung cancer [6]. On the other hand, Palozza et al. demonstrated antioxidative effects of $\beta$-carotene consisting in inhibition of lipid peroxidation caused by tobacco smoke components [7]. Another study showed that lycopene had the most beneficial antioxidative effect [8], while in vivo studies with tomatoes and tomato products containing the highest level of this carotenoid revealed that lycopene prevented DNA damage as well as reduced oxidation of low density lipoproteins and peroxidation of lipids $[9,10]$. In contrast to $\beta$-carotene, lycopene is not transformed into retinol (one of the forms of vitamin A) following intestinal absorption. Thus, it cannot be excluded that this is the reason why the combination of $\beta$-carotene and lycopene is more beneficial than the combination of $\beta$-carotene and vitamin $\mathrm{A}$.

Combination of $\beta$-carotene with $\alpha$-tocopherol - the most important form of vitamin $\mathrm{E}$ in humans - was studied by Albanes et al. in a group of tobacco smokers [11]. Volunteers were divided into three groups: the first group received only $\beta$-carotene, the second group received $\beta$-carotene and $\alpha$-tocopherol, while the third group was the control group receiving no vitamins. Higher incidence of lung, prostate and stomach cancers were observed in the group not receiving $\alpha$-tocopherol as compared to the group receiving combination of vitamins. Subjects receiving combination of $\beta$-carotene and $\alpha$-tocopherol were characterized by lower risk of lung and colorectal cancer while also being at higher risk of stomach cancer compared to the control group. Thus, the results were ambiguous: on one hand, they confirmed the efficacy of vitamin combination while on the other hand, they questioned the very sense of the use of the vitamins. Moreover, Arora et al. proposed a hypothesis that carotenoids had prooxidative activity [12].

All these controversies may be most probably solved only in studies in animal models that would also permit to conduct analyses at the molecular level. In ferrets exposed to the components of tobacco smoke, and receiving high doses of $\beta$-carotene $(30 \mathrm{mg} / \mathrm{d})$, induction of pulmonary cytochrome $\mathrm{P} 450$, increased catabolism of retinoic acid and reduced number of retinoic acid receptors $\beta$ (RAR $\beta$ ) were observed [13]. Reduction in retinoic acid levels and the number of RAR $\beta$ leads to repression of the activator protein 1 transcription factor that takes part in regulation of cell apoptosis, proliferation and differentiation [14].

Insulin-like growth factor (IGF) is an important factor of cell proliferation, differentiation and apoptosis [15]. Insulin-like growth factor binding protein 3 (IGFBP-3) regulates the activity of IGF-1 by blocking its impact on the receptors.
As a result, IGF-1 becomes incapable of exerting its mutagenic effects [16]. IGF-1 is associated with the risk of lung cancer $[13,14]$. In animals receiving lycopene-containing supplements, increase in IGFBP-3 levels and inhibition of the growth of cancer due to the exposure to tobacco smoke were observed $[13,14]$. In other studies, Kim et al. demonstrated that combination of antioxidants ( $\beta$-carotene, $\alpha$-tocopherol and ascorbic acid) caused no change in the protein levels and mRNA expression of IGF-1/IGFBP-3 in lungs and liver [17].

Phosphorylation of cellular tumor antigen 53, a transcription factor, plays an important role in individuals at risk of cancer. In order for p53 to be capable of activating the expression of apoptotic factors, such as Bcl-2-associated X protein, it must undergo appropriate phosphorylation. High doses of $\beta$-carotene were shown to promote phosphorylation of p53 in smokers, thus reducing the risk of cancer in this group [18].

\section{Vitamin D}

As suggested by the results of some studies, vitamin D promotes reduction of risk of lung cancer. It is a strong inhibitor of cancer cell proliferation and angiogenesis, as confirmed by studies conducted in lung carcinoma and neoplastic endothelial cell lines. In addition, vitamin D accelerates differentiation and apoptosis of tumor cells [19].

Unchanged lung cells are characterized by high expression of the vitamin D receptor (VDR) as well as high activity of $1 \alpha$-hydroxylase - an enzyme involved in formation of 1,25-dihydroxycholecalcipherol $\left(1,25(\mathrm{OH})_{2}-\mathrm{D}_{3}\right.$, or calcitriol, an active form of vitamin D) [20]. In tissues infiltrated by lung tumor, both VDR and $1 \alpha$-hydroxylase are inhibited $[21,22]$. Binding of active vitamin D to the VDR receptors increases the immunity of the host as a result of activation of the transcription of genes encoding for antibacterial peptides and CD14 [20]. This mechanism of action of vitamin $\mathrm{D}$ consists in reducing the expression of the vascular endothelial growth factor (VEGF), which is an important marker of angiogenesis. VEGF blocking leads to inhibited proliferation of lung tumor cells [23]. 1,25(OH $)_{2}-\mathrm{D}_{3}$ also suppresses the epidermal growth factor receptor (EGFR) [19]. Overexpression of EGFR is one of the factors responsible for proliferation and lung metastases [23].

Vitamin A plays an important role in VDR regulation. Following activation with ligand, i.e. calcitriol, VDR undergoes heterodimerization with retinoid $\mathrm{X}$ receptor (RXR) to form a VDR-RXR complex. However, exceedingly high systemic levels of 9-cis-retinoid acid (which is the only ligand of the RXR receptor), may interrupt VDR-RXR heterodimerization and promote formation of RXR-RXR homodimers [24]. The antagonistic effect of retinol against vitamin $\mathrm{D}$ was described in cases of pancreatic and colon cancer [25].

Cohort studies conducted by Kilkkinen et al. revealed that women receiving vitamin $\mathrm{D}$ at levels of $>31 \mathrm{nmol} / \mathrm{L}$ 
the risk of lung cancer was reduced by $72-84 \%$ [26]. On the other hand, Freedman et al. observed a nearly non-significant increase in mortality due to lung cancer in women (vitamin D levels of $<50 \mathrm{nmol} / \mathrm{L}$ and $\geq 80 \mathrm{nmol} / \mathrm{L}$ ), but also an increase in the incidence of prostate cancer in men $(<50 \mathrm{nmol} / \mathrm{L}$ and $\geq 100 \mathrm{nmol} / \mathrm{L}$ ) [27].

High doses of vitamin D combined with low doses of retinol $(<2.646 \mathrm{IU} /$ day) reduced the risk of colon cancer. At the same time, the intake of the same combination of vitamins with high doses of retinol ( $>4.784$ IU/day) did not reduce the risk of the disease. On the other hand, high doses of vitamin D combined with calcium reduced the risk of the same type of cancer [28].

Much higher increase in systemic vitamin D levels may contribute to the reduced risk of pancreatic cancer, as demonstrated in the studies by Wolpin et al. [29]. On the other hand, other studies demonstrated that the intake of large quantities of calcium reduced the risk of breast cancer [30]. Unfortunately, the same type of management increased the risk of prostate cancer in males [31].

\section{Vitamin E}

Vitamin $\mathrm{E}$ is a group name of organic compounds consisting of tocopherols $(\alpha, \beta, \gamma$ and $\delta)$ and tocotrienols $(\alpha, \beta$, $\gamma$ and $\delta$ ) [32]. As suggested by the results of some studies, the beneficial form of vitamin $\mathrm{F}$ are tocotrienols (and not, as previously thought, $\alpha$-tocopherol). The results of Women Health Study showed that women receiving daily doses of $\alpha$-tocopherol were at the same risk of lung, breast or colon cancer as patients receiving placebo [33]. On the other hand, Wada et al. presented evidence suggesting that oral administration of tocotrienol-rich fraction (TRF) to mice led to significant reduction in the development of hepatic tumors [34]. Other studies revealed that the treatment of lung tumor cells with TRF containing $\gamma$-tocotrienol as the predominant significantly reduced (from $26 \%$ to $17 \%$ ) the content of 8-hydroxy-2-deoxyguanosine (8-oxo-dG) - a marker of DNA damage due to oxidative stress. Also reduced, from $0.51 \%$ to $0.23 \%$, was the level of $\gamma-\mathrm{H} 2 \mathrm{AX}$ - a relatively recently described biomarker of DNA double strand cleavage. Another consequence consisted in reduced levels of prostaglandin $\mathrm{E}_{2}$ and leukotriene $\mathrm{B}_{4}[35]$. Barve et al. demonstrated that daily administration of TRF to mice for 16 weeks reduced the risk of prostate cancer [36]. Somewhat earlier, the same group of researchers demonstrated similar effects for $\gamma$-tocopherol [37]. The authors suggest that TRF and tocopherols have different mechanism of action with respect to inhibition of carcinogenesis within the prostate. Tocopherol activates detoxication and antioxidative mechanisms whereas TRF components directly modulate the cell cycle and increase the expression of proapoptotic proteins [36]. Promising results were obtained also by Budin et al., who demonstrated that administration of TRF to experimental animals reduced DNA damage as well as suppressed peroxidation of membrane lipids, thus showing antioxidative properties (lower levels of malonic dialdehyde and 4-hydroxynonenal) [38]. These results were confirmed in the studies conducted by Taridi et al. in rats [39] as well as in randomized clinical trials demonstrating reduction in oxidative stress marker levels (8-oxo-dG) in blood samples [40].

Ren et al. fed mice with TRF-enriched mixtures to observe significant proliferation of lymphocytes [41]. It turned out that TRF is capable of stimulating the immune system to produce immune cells.

Rapid elimination of cancer stem cells (CSC) allows suppression of further development of the disease. Ren et al. demonstrated that $\gamma$-tocopherol might be a factor limiting the CSC growth [42]. This form of vitamin $\mathrm{E}$ is also capable of inhibiting the expression of CSC markers, $\beta$-catenins. Studies in mice revealed that oral $\gamma$-tocopherol causes suppression of more than $70 \%$ of CSCs.

Liu et al. used $\gamma$-tocopherol for the treatment of gastric adenocarcinoma [43]. The observed result was inhibition of tumor cell migration thanks to the reduction in the transcription of genes encoding for metalloproteinases MMP-2 and MMP-9, as well as to inhibition of the activity of tissue inhibitors of metalloproteinases TIMP-1 and TIMP-2. $\gamma$-Tocopherol also increased the expression of epithelial markers, E-cadherin and $\gamma$-catenin. At the same time, reduction in the levels of mesenchymal markers, vimentin and $\alpha$-actin in smooth muscle cells is observed. As shown by these findings, the use of $\gamma$-tocopherol in therapy may facilitate inhibition of tumor cells by reversing the epithelial-mesenchymal transition (EMT). EMT is the main mechanism responsible for metastasis and recurrence of cancer [44, 45].

\section{Vitamin C}

Results of different studies suggest beneficial effects of ascorbic acid and reveal relationships between its levels in plasma and prognosis in certain disorders. An example of such relationship was presented by Mayland et al. who examined plasma levels of vitamin $\mathrm{C}$ in patients with terminal-stage cancer [46]. High levels of C-reactive protein (CRP) combined with low levels of vitamin $\mathrm{C}$ were correlated with shorter survival times.

Ascorbic acid is a vitamin capable of destroying tumor cells. Among its other effects, it enhances the activity of caspases, demonstrating proapoptotic activity. During vitamin C-enhanced apoptosis of tumor cells, proliferation of mutated cells is also inhibited. Vitamin $\mathrm{C}$ also blocks the cell cycle and induces the cell to enter the $G_{0} / G_{1}$ phase. In addition, treatment of tumor cells with ascorbic acid increases their susceptibility to cytostatic drugs. In this case, the mechanism of action of vitamin $\mathrm{C}$ is probably associated with disturbed synthesis of nucleic acids and inhibition of cell cycle progression [47]. However, it should be noted that the effect is not observed for all cytostatic drugs. Heaney et al. concluded that both the cellular location of the activity and the dose of ascorbic acid have a significant impact 
on whether the vitamin acts in a manner that is synergistic, or antagonistic to the effect of cytostatic drugs [48]. This position was confirmed in studies conducted in tumor cell lines such as neuroblastoma [49], urinary bladder [50], pancreatic [51] and liver cancers [52].

Ascorbic acid also inhibits the development of tumor cells by inhibition of angiogenesis [53]. This was demonstrated by Yeom et al. who parenterally administered vitamin $\mathrm{C}$ to mice, achieving suppression of angiogenesis and reduction in the expression of proangiogenic factors: basic fibroblast growth factor, VEGF and matrix metalloproteinase-2 (MMP-2) [54]. Ascorbic acid also suppressed hypoxia induced factor-1, which is critical in stimulation of tumor angiogenesis [54].

In certain conditions, ascorbic acid may reduce the system's immunity. High doses of vitamin $\mathrm{C}$ inhibit proliferation of natural killers, as well as lymphocytes $\mathrm{T}$ and $\mathrm{B}$ responsible for secretion of IL-2. In addition, ascorbic acid blocks activation of lymphocytes $\mathrm{T}$ which are forced to adopt immature form following stimulation by dendritic cells [55].

Ascorbic acid is often used in combination with other antioxidants. In studies conducted by Banim et al., high doses of vitamin $\mathrm{C}$ administered in combination with vitamin $\mathrm{E}$ and selenium reduced the risk of pancreatic cancer while showing no statistically significant beneficial effects when administered separately [56]. Similar results were presented by Bravi et al., who observed reduction in the risk of pancreatic cancer following combined administration of vitamins $\mathrm{C}$ and $\mathrm{E}, \beta$-carotene and lutein/zeaxanthin [57]. On the other hand, Heinen et al. were unable to confirm the correlation between supplementation with antioxidants together with the intake of selected vegetables and fruits and the reduced risk of pancreatic cancer [58].

Steevens et al. reported reduced incidence of esophageal cancer in a group of heavy smokers correlated with intake of raw vegetables and citrus fruits (rich in vitamin C) [59]. Similarly, in the studies conducted by Murphy et al., effects of vitamin $\mathrm{C}$ were associated with reduced risk of esophageal cancer [60]. No effects were observed for vitamin E, carotenoids and selenium when administered separately. Beneficial effect could only be observed when all compounds were used in combination with vitamin $\mathrm{C}$.

\section{Resume}

As shown by the presented literature review, the use of vitamin supplements is not always desirable, while being straightforwardly hazardous in certain cases. Although the results of studies conducted to date are controversial and require confirmation in a larger study material, there is no doubt that the intake of vitamin supplements should be controlled and strictly supervised by physicians in high risk patients. In this context, the wide and unlimited availability of this type of preparations becomes not only a health problem, but an ethical problem as well.

\section{References}

1. Peto R., Doll R., Buckley J.D., Sporn M.B.: Can dietary beta-carotene materially reduce human cancer rates? Nature. 1981, 290 (5803), 201-208.

2. Graham S.: Diet and cancer. Am J Epidemiol. 1980, 112 (2), 247-252.

3. Lippman S.M., Benner S.E., Hong W.K.: Retinoid chemoprevention studies in upper aerodigestive tract and lung carcinogenesis. Cancer Res. 1994, 54, Suppl. 7, 2025-2028.

4. Greenberg E.R., Baron J.A., Stukel T.A., Stevens M.M., Mandel J.S., Spencer S.K. et al.: A clinical trial of beta carotene to prevent basal-cell and squamous-cell cancers of the skin. The Skin Cancer Prevention Study Group. N Engl J Med. 1990, 323 (12), 789-795.

5. Omenn G.S., Goodman G.E., Thornquist M.D., Balmes J., Cullen M.R., Glass A. et al:: Effects of a combination of beta carotene and vitamin A on lung cancer and cardiovascular disease. N Engl J Med. 1996, 334 (18), 1150-1155.

6. Michaud D.S., Feskanich D., Rimm E.B., Colditz G.A., Speizer F.E., Willett W.C. et al.: Intake of specific carotenoids and risk of lung cancer in 2 prospective US cohorts. Am J Clin Nutr. 2000, 72, 990-997.

7. Palozza P., Serini S., Trombino S., Lauriola L., Ranelletti F.O., Calviello $G$.: Dual role of $\beta$-carotene in combination with cigarette smoke aqueous extract on the formation of mutagenic lipid peroxidation products in lung membranes: dependence on $\mathrm{pO}_{2}$. Carcinogenesis. 2006, 27, 2383-2391.

8. Krinsky N.I., Johnson E.J.: Carotenoid actions and their relation to health and disease. Mol Aspects Med. 2005, 26, 459-516.

9. Wertz K., Siler U., Goralczyk R.: Lycopene: modes of action to promote prostate health. Arch Biochem Biophys. 2004, 430, 127-134.

10. Rao A.V., Ray M.R., Rao L.G.: Lycopene. Adv Food Nutr Res. 2006, 51, 99-164.

11. Albanes D., Heinonen O.P., Huttunen J.K., Taylor P.R., Virtamo J., Edwards B.K. et al.: Effects of alpha-tocopherol and beta-carotene supplements on cancer incidence in the alpha-tocopherol beta-carotene cancer prevention study. Am J Clin Nutr. 1995, 62, Suppl. 6, 1427-1430.

12. Arora A., Willhite C.A., Liebler D.C.: Interactions of $\beta$-carotene and cigarette smoke in human bronchial epithelial cells. Carcinogenesis. 2001, 22, 1173-1178.

13. Liu C., Russell R.M., Wang X.D.: Exposing ferrets to cigarette smoke and a pharmaco-logical dose of $\beta$-carotene supplementation enhance in vitro retinoic acid catabolism in lungs via induction of cytochrome P450 enzymes. J Nutr. 2003, 133, 173-179.

14. Kim J., Kim Y.: Animal models, carotenoids research and lung cancer prevention. Transl Oncol. 2011, 4 (5), 271-281.

15. Yu H., Rohan T.: Role of the insulin-like growth factor family in cancer development and progression. J Natl Cancer Inst. 2000, 92, 1472-1489.

16. Liu B., Lee H.Y., Weinzimer S.A., Powell D.R., Clifford J.L., Kurie $J . M$. et al.: Direct functional interactions between insulin-like growth factorbinding protein- 3 and retinoid $\mathrm{X}$ receptor- $\alpha$ regulate transcriptional signaling and apoptosis. J Biol Chem. 2000, 275 (43), 33607-33613.

17. Kim Y., Lian F., Yeum K.J., Chongviriyaphan N., Choi S.W., Russell R.M. et al.: The effects of combined antioxidant ( $\beta$-carotene, $\alpha$-tocopherol and ascorbic acid) supplemen-tation on antioxidant capacity, DNA single-strandbreaks and levels of insulin-like growth factor-1/IGF-binding protein 3 in the ferret model of lung cancer. Int J Cancer. 2007, 120, 1847-1854.

18. Liu C., Russell R.M., Wang X.D.: Low dose $\beta$-carotene supplementation of ferrets attenuates smoke-induced lung phosphorylation of JNK, p38, MAPK, and p53 proteins. J Nutr. 2004, 134, 2705-2710.

19. Deeb K.K., Trumpo D.L., Johnson C.S.: Vitamin D signaling pathways in cancer: poten-tial for anticancer therapeutics. Nat Rev Cancer. 2007, 7, 684-700.

20. Hansdottir S., Monick M.M., Hinde S.L., Lovan N., Look D.C., Hunninghake G.W.: Respiratory epithelial cells convert inactive vitamin $\mathrm{D}$ to its active form: potential effects on host defense. J Immunol. 2008, 181, 7090-7099. 
21. Menezes R.J., Cheney R.T., Husain A., Tretiakova M., Loewen G., Johnson C.S. et al.: Vitamin D receptor expression in normal, premalignant, and malignant human lung tissue. Cancer Epidemiol Biomarkers Prev. 2008, 17 (5), 1104-1110.

22. Turner A.M., McGowan L., Millen A., Rajesh P., Webster C., Langman G. et al.: Circulating DBP level and prognosis in operated lung cancer: an exploration of pathophysiology. Eur Respir J. 2013, 41 (2), 410-416.

23. Herbst R.S., Heymach J.V., Lippman S.M.: Lung cancer. N Engl J Med. 2008, 25, 359 (13), 1367-1380.

24. Cheng T.Y., Neuhouser M.L.: Serum 25-hydroxyvitamin D, vitamin A, and lung cancer mortality in the US population: a potential nutrient-nutrient interaction. Cancer Causes Control. 2012, 23 (9), 1557-1565.

25. Bao Y., Ng K., Wolpin B.M., Michaud D.S., Giovannucci E., Fuchs C.S.: Predicted vitamin D status and pancreatic cancer risk in two prospective cohort studies. Br J Cancer. 2010, 102 (9), 1422-1427.

26. Kilkkinen A., Knekt P., Heliövaara M., Rissanen H., Marniemi J., Hakulinen T. et al.: Vitamin D status and the risk of lung cancer: a cohort study in Finland. Cancer Epidemiol Biomarkers Prev. 2008, 17 (11), 3274-3278.

27. Freedman D.M., Looker A.C., Abnet C.C., Linet M.S., Graubard B.I.: Serum 25-hydroxyvitamin D and cancer mortality in the NHANES III study (1988-2006). Cancer Res. 2010, 70 (21), 8587-8597.

28. Oh K., Willett W.C., Wu K., Fuchs C.S., Giovannucci E.L.: Calcium and vitamin $\mathrm{D}$ intakes in relation to risk of distal colorectal adenoma in women. Am J Epidemiol. 2007, 165 (10), 1178-1186.

29. Wolpin B.M., Ng K., Bao Y., Kraft P., Stampfer M.J., Michaud D.S. et al.: Plasma 25-hydroxyvitamin D and risk of pancreatic cancer. Cancer Epidemiol Biomarkers Prev. 2012, 21 (1), 82-91.

30. Chen P., Hu P., Xie D., Qin Y., Wang F., Wang H.: Meta-analysis of vitamin $\mathrm{D}$, calcium and the prevention of breast cancer. Breast Cancer Res Treat. 2010, 121 (2), 469-477.

31. Van Poppel H., Tombal B.: Chemoprevention of prostate cancer with nutrients and supplements. Cancer Manag Res. 2011, 3, 91-100.

32. Ling M.T., Luk S.U., Al-Ejeh F., Khanna K.K.: Tocotrienol as a potential anticancer agent. Carcinogenesis. 2012, 33 (2), 233-239.

33. Lee I.M., Cook N.R., Gaziano J.M., Gordon D., Ridker P.M., Manson J.E. et al.: Vitamin $\mathrm{E}$ in the primary prevention of cardiovascular disease and cancer: the Women Health Study: a randomized controlled trial. JAMA. 2005, 294, 56-65.

34. Wada S., Satomi Y., Murakoshi M., Noguchi N., Yoshikawa T., Nishino H.: Tumor suppressive effects of tocotrienol in vivo and in vitro. Cancer Lett. 2005, 229, 181-191.

35. Yang C.S., Suh N.: Cancer prevention by different forms of tocopherols. Top Curr Chem. 2013, 329, 21-34.

36. Barve A., Khor T.O., Reuhl K., Reddy B., Newmark H., Kong A.N.: Mixed tocotrienols inhibit prostate carcinogenesis in TRAMP mice. Nutr Cancer. 2010, 62, 789-794.

37. Barve A., Khor T.O., Nair S., Reuhl K., Suh N., Reddy B. et al.: Gamma-tocopherol-enriched mixed tocopherol diet inhibits prostate carcinogenesis in TRAMP mice. Int J Cancer. 2009, 124, 1693-1699.

38. Budin S.B., Othman F., Louis S.J., Bakar M.A., Das S., Mohamed $J .:$ The effects of palm oil tocotrienol-rich fraction supplementation on biochemical parameters, oxidative stress and the vascular wall of streptozotocin-induced diabetic rats. Clinics. 2009, 64, 235-244.

39. Taridi N.M., Yahaya M.F., Teoh S.L., Latiff A.A., Ngah W.Z., Das S. et al.: Tocotrienol rich fraction (TRF) supplementation protects against oxidative DNA damage and improves cognitive functions in Wistar rats. Clin Ter. 2011, 162, 93-98.

40. Chin S.F., Hamid N.A., Latiff A.A., Zakaria Z., Mazlan M., Yusof Y.A. et al:: Reduction of DNA damage in older healthy adults by Tri E Tocotrienol supplementation. Nutrition. 2008, 24 (1), 1-10.

41. Ren Z., Pae M., Dao M.C., Smith D., Meydani S.N., Wu D.: Dietary supplementation with tocotrienols enhances immune function in $\mathrm{C} 57 \mathrm{BL} / 6$ mice. J Nutr. 2010, 140, 1335-1341.
42. Ren Z., Pae M., Dao M.C., Smith D., Meydani S.N., Wu D.: Gamma-tocotrienol as an effective agent in targeting prostate cancer stem cell-like population. Int J Cancer. 2010, 128, 2182-2191.

43. Liu H.K., Wang Q., Li Y., Sun W.G., Liu J.R., Yang Y.M. et al.: Inhibitory effects of gamma-tocotrienol on invasion and metastasis of human gastric adenocarcinoma SGC-7901 cells. J Nutr Biochem. 2010, 21, 206-213.

44. Yap W.N., Chang P.N., Han H.Y., Lee D.T., Ling M.T., Wong Y.C. et al.: Gamma-tocotrienol suppresses prostate cancer cell proliferation and invasion through multiple-signalling pathways. Br J Cancer. 2008, 99, 1832-1841.

45. Chang P.N., Yap W.N., Lee D.T., Ling M.T., Wong Y.C., Yap Y.L.: Evidence of gamma-tocotrienol as an apoptosis-inducing, invasion-suppressing, and chemotherapy drug-sensitizing agent in human melanoma cells. Nutr Cancer. 2009, 61 (3), 357-366.

46. Mayland C.R., Bennett M.I., Allan K.: Vitamin C deficiency in cancer patients. Palliat Med. 2005, 19, 17-20.

47. Frömberg A., Gutsch D., Schulze D., Vollbracht C., Weiss G., Czubayko F. et al:: Ascorbate exerts anti-proliferative effects through cell cycle inhibition and sensitizes tumor cells towards cytostatic drugs. Cancer Chemother Pharmacol. 2011, 67, 1157-1166.

48. Heaney M.L., Gardner J.R., Karasavvas N., Golde D.W., Scheinberg D.A., Smith E.A. et al.: Vitamin C antagonizes the cytotoxic effects of antineoplastic drugs. Cancer Res. 2008, 68, 8031-8038.

49. Deubzer B., Mayer F., Kuçi Z., Niewisch M., Merkel G., Handgretinger R. et al.: $\mathrm{H}_{2} \mathrm{O}_{2}$-mediated cytotoxicity of pharmacologic ascorbate concentrations to neuroblastoma cells: potential role of lactate and ferritin. Cell Physiol Biochem. 2010, 25 (6), 767-774.

50. Gilloteaux J., Jamison J.M., Neal D.R., Loukas M., Doberzstyn T., Summers J.L.: Cell damage and death by autoschizis in human bladder (RT4) carcinoma cells resulting from treatment with ascorbate and menadione. Ultrastruct Pathol. 2010, 34 (3), 140-160.

51. Cullen J.J.: Ascorbate induces autophagy in pancreatic cancer. Autophagy. 2010, 6 (3), 421-422.

52. Verrax J., Pedrosa R.C., Beck R., Dejeans N., Taper H., Calderon P.B.: In situ modulation of oxidative stress: a novel and efficient strategy to kill cancer cells. Curr Med Chem. 2009, 16, 1821-1830.

53. Ichim T.E., Minev B., Braciak T., Luna B., Hunninghake R., Mikirova N.A. et al.: Intravenous ascorbic acid to prevent and treat cancer-associated sepsis? J Transl Med. 2011, 9, 25.

54. Yeom C.H., Lee G., Park J.H., Yu J., Park S., Yi S.Y. et al.: High dose concentration administration of ascorbic acid inhibits tumor growth in BALB/C mice implanted with sarcoma 180 cancer cells via the restriction of angiogenesis. J Transl Med. 2009, 7, 1-9.

55. Tan P.H., Sagoo P., Chan C., Yates J.B., Campbell J., Beutelspacher S.C. et al:: Inhibition of NF-kappa B and oxidative pathways in human dendritic cells by antioxidative vitamins generates regulatory $\mathrm{T}$ cells. J Immunol. 2005, 174, 7633-7644.

56. Banim P.J., Luben R., McTaggart A., Welch A., Wareham N., Khaw K.T. et al.: Dietary antioxidants and the aetiology of pancreatic cancer: a cohort study using data from food diaries and biomarkers. Gut. 2012, 62 (10), 1489-1496.

57. Bravi F., Polesel J., Bosetti C., Talamini R., Negri E., Dal Maso L. et al.: Dietary intake of selected micronutrients and the risk of pancreatic cancer: an Italian case-control study. Ann Oncol. 2011, 22, 202-206.

58. Heinen M.M., Verhage B.A., Goldbohm R.A., van den Brandt P.A.: Intake of vegetables, fruits, carotenoids and vitamins $\mathrm{C}$ and $\mathrm{E}$ and pancreatic cancer risk in The Netherlands Cohort Study. Int J Cancer. 2012, 130, 147-158.

59. Steevens J., Schouten L.J., Goldbohm R.A., van den Brandt P.A.: Vegetables and fruits consumption and risk of esophageal and gastric cancer subtypes in the Netherlands Cohort Study. Int J Cancer. 2011, 129, 2681-2693.

60. Murphy S.J., Anderson L.A., Ferguson H.R., Johnston B.T., Watson P.R., McGuigan J. et al.: Dietary antioxidant and mineral intake in humans is associated with reduced risk of esophageal adenocarcinoma but not reflux esophagitis or Barrett's esophagus. J Nutr. 2010, 140, 1757-1763. 